\title{
THE APPLICATION OF RISK MANAGEMENT TO MINIMIZE THE RISK OF BAD DEBTS IN PT. BANK MANDIRI
}

\author{
Dwi Urip Wardoyo', Emeralda Diva Vania ${ }^{2}$, Septiani Wahyuningrum³ \\ ${ }^{1,2,3}$ Accounting Study Program, Faculty of Economic and Business, Telkom University, \\ Bandung \\ Email: dwiurip@telkomuniversity.ac.id
}

\begin{abstract}
The important sector in economic growth in Indonesia is the banking sector. The banking sector is a community fund collection institution. Until now the existence of the banking sector has increased, it also makes there an increase in risk. This increase is characterized by the increasing distribution of public funds to the banking sector. Due to the large amount of these funds, as for the regulations issued by Bank Indonesia regarding the implementation of risk management for commercial banks with Bank Indonesia Circular Letter No.7/3DPNP dated January 31, 2015. This research aims to find out the application of risk management at PT Bank Mandiri. The type of research is descriptive research with a qualitative approach. The results of this study show that PT Bank Mandiri has implemented good risk management to minimize problem credit well in accordance with the provisions of Bank Indonesia and is able to maintain the average level of Non-Performing Loan (NPL), the NPL figure will show the percentage of problematic credit from all credits launched to the public.
\end{abstract}

Keywords: Risk Management, Minimizing Problematic Credit, Non-Performing Loan (NPL).

\section{A. INTRODUCTION}

Banks are financial institutions that have the main activity of accepting demand deposits, savings and deposits. The business world is also related to the bank because it is an influential sector, especially in the life of modern society where almost all of them use the services of the banking sector. People have increasing trust in banks, so the products and services offered are also increasingly varied by providing services with maximum quality.

Developments in the banking sector are accelerating at a very fast pace, accompanied by increasingly complex business activities of banks and ever-increasing credit exposures, this can stimulate an increase in risks faced by banks. Therefore, banks currently need to implement risk management, which is also related to credit risk management in accordance with Bank Indonesia (BI) policies.

According to (Kasmir 2016:73) explains that financing or credit is a facilitator of money or bills that can be equated with it, based on an agreement between the bank and another party by requiring the party to return the money or bill within a certain period of time. The financing or credit provided carries risks, so that in its implementation it is necessary to pay attention to credit rules properly because it can be a credit risk. Credit risk is the risk from the impact of the failure of the debtor or other party to fulfill obligations to the bank, credit grows into a problem due to various things originating from the customer (Financial Services Authority, 2016).

Credit risk management must be carried out properly, because when it is not managed properly or optimally it can cause the balance of non-performing loans to become large which can have a negative impact on banking. Among various banks in Indonesia, PT Bank Mandiri 
has a role as a supporter of economic recovery after the Covid-19 pandemic, because the Covid-19 pandemic can worsen the economy which is predicted that banks will face bad loans.

PT Bank Mandiri Persero has won the best bank award in the company's banking sector at the Bisnis Indonesia Award or BIA 2021 event which was held virtually. This proves that PT Bank Mandiri is transforming in improving service quality and contributing to boosting the Indonesian economy in the midst of the Covid-19 outbreak. The Bisnis Indonesia Award (BIA) is an annual activity from the Indonesian business group, this award is given as a trusted business navigation for business people in Indonesia who are listed on the Indonesia Stock Exchange (IDX). However, in the credit distribution process, everything is not necessarily smooth and free from credit risk. For this reason, loans disbursed by banks need to be managed properly so as to minimize losses that have a positive impact on the development and progress of the Indonesian economy.

The formulation of the problem from this research, namely:

1. How is the implementation of risk management at PT Bank Mandiri in minimizing the risk of bad loans?

2. How does the application of risk management affect the level of Non-Performing Loans (NPL) or bad loans at PT Bank Mandiri?

The objectives of the research carried out are:

1. Knowing the application of risk management at PT Bank Mandiri in minimizing the risk of bad loans.

2. Knowing that the application of risk management can minimize the level of NonPerforming Loans (NPL) or bad loans at PT Bank Mandiri.

\section{B. LITERATURE REVIEW}

\section{Agency Theory}

Management and company ownership are now separated by companies. This is in accordance with the agency theory (Agency Theory) which explains that there are assignments in managing the company to professional personnel (agents). The concept of agency theory is a contractual relationship between the principal and the agent (Supriyono 2018:63). The relationship is carried out to provide a service where the principal gives authority to the agent about making the best provisions for the principal by prioritizing the company to get maximum profit and be able to manage costs optimally. The granting of authority to agents to manage the company allows a conflict of interest between management. Based on this, it can be concluded that there is an opportunity to blame one party for an act that provides benefits for its own interests.

\section{Risk Management}

Running a company's business requires one important basis, namely risk management because developments in the business world and the increasing complexity of company activities can result in an increased level of risk faced by the company (Opan Arifudin, 2020). Risk management aims to manage the risks that exist in the company so that it can prevent the company from the risk of failure in its business operations. The importance of 
understanding risk management is useful for management to face uncertainty with the risks and opportunities faced by the company in daily business operations.

\section{Credit}

Credit is the first party to provide performance which can be in the form of money, goods, services to other parties, while the reciprocity will be received within the agreed period (Thamrin \& Sintha 2018:112).

Credit has several functions as follows:

a. Increase the usability of money

The existence of credit can increase the usability of money, which means that if money is only saved then the money cannot produce anything useful.

b. Increase the circulation of money

An increase in the circulation of money occurs because the money given or distributed will circulate from one area to another, so that areas that are short of money by getting credit will get money from other regions.

c. A tool for economic stability

The existence of credit can increase the number of goods needed by the community.

d. Increase the desire to do business

The number of credits given will be better, especially to increase income in a business.

\section{Non-Performing Loan}

Non-Performing Loans (NPL) in the form of arrears that experience obstacles in repayment, non-performing loans are another name for Non-Performing Loans. Nonperforming loans have an influence on banking credit distribution with credit that has poor credit quality or commonly known as non-performing loans (Putri, 2017). According to the Circular Letter of Bank Indonesia No.12/11/DPNP/2010, non-performing loans are loans that have non-current, doubtful and bad quality. The assessment of non-performing loans is based on the existence of credit payments by customers seen in the bank's bookkeeping records. This note contains the terms of payment of principal, interest, and other obligations. Based on the customer's performance in this regard, the bank makes an assessment based on the historical data of each customer. According to (Kasmir, 2016), these non-performing loans can be overcome by rescheduling, re-conditioning, realignment, combination, and foreclosure of collateral.

\section{Bad Loans Rescue}

According to (Fachrizah, 2021) programs to rescue bad loans are generally divided into three types. namely:

a. Rescheduling is a form of effort to make changes to some of the terms of the agreement in the credit agreed at the beginning. This rescheduling is carried out in order to extend the due date for payment of obligations without making changes to the remaining customer obligations that must be paid. 
b. Reconditioning is a change in part or all of the terms of the agreement in which the debtor is expected to pay off his obligations. This program can be given to debtors in the form of waiving some of the interest in arrears, reducing interest rates.

c. Restructuring the form of business in changing the terms of the credit agreement in the form of additional credit or transforming all or part of the credit into equity company.

\section{Thinking Framework}

The application of risk management is a protection for the company against possible losses. The implementation of risk management in banks must cover various risks such as market risk, credit risk, liquidity risk and operational risk. Risk management is a systematic method of identifying, determining attitudes, determining solutions as well as carrying out monitoring and reporting of ongoing risks in each of its activities. In this study, the application of risk management is used to minimize credit risk, the risk caused by nonperforming loans. The emergence of non-performing loans is mostly not sudden, this happens because the basis for non-performing loans is a process. The existence of unfavorable symptoms that lead to non-performing loans, if the symptoms that can cause non-performing loans can be detected correctly and correctly, then the problem of problem loans can be minimized properly.

Based on the above theory that the application of risk management can minimize the risk of bad credit that occurs in banking. This research is in accordance with the results of the research by Pratama and A. Samiun (2019) which stated that the risk management of BPRS Bahari Berkesan in general has shown results that are in line with expectations, which are related to applying risk management principles to minimize financing/credit. As for other previous studies, the results of which show that the implementation of risk management at Bank Muamalat KCP Palopo by carrying out four stages, namely identification, measurement, monitoring, and control which shows that risk management can minimize credit risk that occurs with good risk management (Musdahlia, 2020).

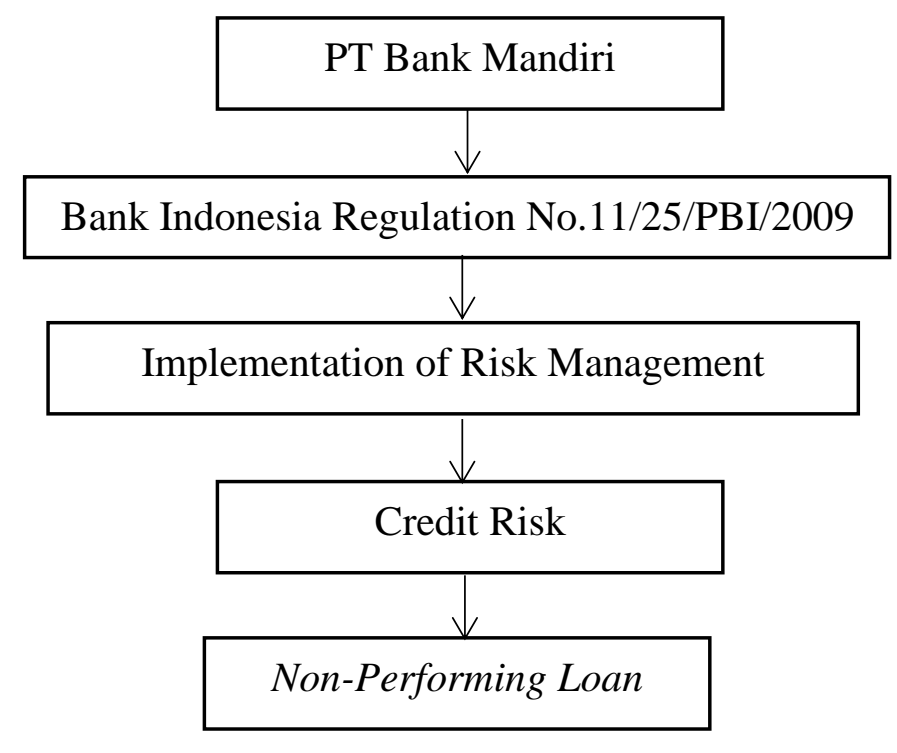

Figure 1 Thinkinh Framework

Source: data processed by the author (2021) 


\section{Previous Research}

Pratama \& A. Samiun (2019) have conducted a similar study with the title "Application of Risk Management to Minimize Bad Credit Risk at PT BPRS Bahari Berkesan", in this study the authors conclude that the cause of bad loans is employee weakness in analyzing credit, weak policies, SOPs, and the lack of information received by banks. In addition, this study states that the risk management of BPRS Bahari Berkesan is in line with expectations and is considered quite effective in managing credit risk. In addition, there is another study from (Desda \& Yurasti, 2019) with the research title "Analysis of Application of Credit Risk Management in Minimizing Non-Performing Loans at PT BPR Swadaya Anak Nagari Bandarejo Simpang Empat Period 2013-2018", in this study the author concludes that the application of risk management at PT BPR SAN Bandarejo Simpang Empat has implemented well.

\section{METHOD}

The type of research from the level of explanation is divided into several, namely descriptive, comparative, and associative (Sugiyono, 2018). This research is a descriptive study using a qualitative approach. The aim is to be able to find out in depth which is able to provide answers to the formulation of the problem that has been determined by the author.

The population of this research is PT Bank Mandiri. The author uses a sample in the form of secondary data that has been obtained from documents originating from PT Bank Mandiri. The type of data used in this study is qualitative data which is non-numerical and cannot be measured numerically. The data is data taken from the company's annual report which contains the history, vision and mission of the company, a description of the company's operations, and organizational structure.

The analytical method used in this research is to design the method or method used to obtain complete data from the company. After the data is collected, the author will conduct an analysis of the application of credit risk management and efforts to handle problematic loans at PT Bank Mandiri. This risk management analysis includes (1) active supervision of the board of commissioners and directors; (2) Policies, procedures, and setting limits; (3) The process of identifying, measuring, monitoring, and risk management information systems; and (4) internal control system.

Based on the provisions of Bank Indonesia that a bank must have an NPL below 5\%, the author will conduct an analysis related to the level of non-performing loans at PT Bank Mandiri using the following formula:

$$
\text { Non }- \text { Performing Loan }=\frac{\text { Kredit Substandard }+ \text { Doubtful Loans }+ \text { NPL }}{\text { Total Kredit Given }} \times 100 \%
$$

\section{RESULTS}

\section{Risk in PT Bank Mandiri and Risk Manajement Process}

PT Bank Mandiri in an effort to build awareness and a risk management culture for all risks faced by the company in its business processes on an ongoing basis always conveys the entire implementation of risk management carried out by management in their annual reports. The company also implements a Risk Control Self-Assessment (RCSA) which requires each department to carry out a risk assessment that occurs in its operational activities. 


\section{Credit Risk Management}

PT Bank Mandiri by submitting the disclosure of credit risk exposure per Region, Term, and Economic Sector every year which is listed in the company's annual report. The company also implements a policy of prioritizing the principle of prudence in mitigating credit risk, including provision for impairment losses on assets owned by the company.

PT Bank Mandiri carries out credit risk management in accordance with regulations and circulars issued by the Financial Services Authority (OJK). The company has reported the implementation of credit risk management related to counterparty credit risk since January 2018 and credit valuation adjustment risk weighted assets since January 2017 to the OJK. Bank Mandiri also uses a rating scale in calculating risk-weighted assets for the implementation of credit risk management.

\section{Market Risk Management}

PT Bank Mandiri, in improving the quality and quantity of bank capital in order to minimize losses caused by the financial and economic crisis, has calculated the minimum capital adequacy requirement using the standard method reported to the OJK. The company also performs calculations using value at risk calculations to assess the maximum capacity for losses experienced by banks as a result of market movements that affect the bank's risk exposure in normal market conditions.

\section{Operational Risk Management}

PT Bank Mandiri implements several provisions in their operational risk management, namely simulation of the worst conditions and stress testing as well as an action plan (recovery plan). The company carries out this policy to assess the level of resilience in the face of extreme external scenarios that may occur and apply stress testing as a basis for decision making. This is also related to the economic situation in the past few years until now when Covid-19 occurred throughout the world and affected all aspects of life.

\section{Liquidity Risk Management}

PT Bank Mandiri implements liquidity risk management by measuring the liquidity risk faced by banks using several indicators, such as the primary reserve ratio, secondary reverse, macroprudential intermediation ratio, liquidity coverage ratio, and net stable funding ratio. This calculation is carried out by the company in an effort to measure the obligation to fulfill the liquidity adequacy ratio for banks that have been determined by the Financial Services Authority (OJK).

\section{Legal Risk Management}

PT Bank Mandiri also carries out legal risk management carried out by the legal unit at the Head Office. This unit has functions, duties and responsibilities related to regulatory, advisory, litigation, advocacy and legal assistance, education and transformation in the field of law as well as bank legal risk management. Bank Mandiri's preventive and repressive legal risk management is sufficient to protect legal interests and minimize significant impacts financial for the company. 


\section{Risk Management Strategic}

PT Bank Mandiri has established a risk management committee and a risk management work unit with the aim of supporting a comprehensive, integrated, measurable and controlled risk management. These committees are supported by a working group consisting of groups related to risk issues that are included in the scope of the committee. The company always reviews the performance and evaluates the policies for preparing business targets by improving the preparation of strategic plans and business targets by considering internal and external conditions.

\section{Compliance Risk Management}

PT Bank Mandiri has determined that all levels of the company are fully responsible for complying with each of their respective activities. The compliance risk management policies and procedures made by the company are based on the applicable rules and regulations. The company performs several stages in the implementation of compliance risk management, namely identification, assessment, monitoring, and mitigation.

\section{Reputational Risk Management}

PT Bank Mandiri manages reputation risk through monitoring, supervision, handling and settlement mechanisms which are coordinated by the Corporate Secretary with the support of related work units. Reputation risk management is carried out with reference to internal provisions and applicable laws and regulations. One form of reputation risk management is to create a positive perception through the publication of articles through the media.

\section{Intra Group Transaction Risk Management}

PT Bank Mandiri in managing the risk of intra-group transactions in cooperation with subsidiaries within the Bank Mandiri business group in accordance with the business strategy that has been determined by the company. Bank Mandiri always identifies and analyzes activities that can affect the company's performance.

\section{Insurance Risk Management}

PT Bank Mandiri through its subsidiaries that run the insurance business implements insurance risk management in accordance with the stipulated provisions. Bank Mandiri carries out identification and analysis of activities that can increase insurance risk exposure that affect the company's performance.

\section{Evaluation of the Effectiveness of Risk Management and Implementation of the Risk Management System \\ PT Bank Mandiri always evaluates the effectiveness of the risk management system.} The evaluation includes adjustments to the strategy and risk framework as part of risk management. The form of evaluation in the risk management policy at PT Bank Mandiri is an annual evaluation of Bank Mandiri's risk management policy (KMRBM) and standard procedures. 
The evaluation process on the implementation of risk management in banks is carried out by means of a tiered mechanism, this discussion starts from a technical meeting which is discussed again in the working group and is also approved by the board of directors. The results of the evaluation of risk effectiveness at PT Bank Mandiri show that risk management at Bank Mandiri during 2017 to 2020.

\section{E. DISCUSSION}

\section{Implementation of PT Bank Mandiri's Risk Management}

PT Bank Mandiri has implemented all necessary risk management implementations. The company has several principles in implementing risk management, namely capital, transparency, independence, integration, sustainability, accountability, responsibility, and fairness. The following is a table self-assessment of PT Bank Mandiri's risk profile.

Table 1. Self-Assessment of Bank Mandiri Risk Profile 2017-2020

\begin{tabular}{|l|l|l|l|l|}
\hline \multirow{2}{*}{ Type of Risk } & \multicolumn{4}{l}{ Rating level risk } \\
\cline { 2 - 5 } & $\mathbf{2 0 1 7}$ & $\mathbf{2 0 1 8}$ & $\mathbf{2 0 1 9}$ & $\mathbf{2 0 2 0}$ \\
\hline Credit Risk & LM & LM & LM & LM \\
\hline Market Risk & L & L & L & L \\
\hline Liquidity Risk & L & L & L & L \\
\hline Operational Risk & LM & LM & M & M \\
\hline Legal Risk & L & L & L & L \\
\hline Strategic Risk & L & L & L & L \\
\hline Compliance Risk & L & L & LM & LM \\
\hline Reputational Risk & L & L & L & L \\
\hline Composite Rating & L & L & LM & LM \\
\hline
\end{tabular}
Information:

Source: PT Bank Mandiri Annual Report (processed. 2021)

L : Low

LM : Low to Moderate

M : Moderate

$\mathrm{H}$ : High

Based on table 1, it can be seen that the results of the self-assessment of the risk profile of PT Bank Mandiri (Persero) Tbk as a whole in 2017 to 2018 obtained selfassessment assessment the same, namely credit risk, operational risk received a assessment low to moderate, while other types of risk get a low rating. Similar to the previous year, in 2019 to 2020 PT Bank Mandiri (Persero) Tbk obtained the results self-assessment same as those that received a assessment, moderate only one type of risk, namely operational risk and received 2 low-to-moderate assessments, namely compliance risk and composite rating, while other types of risk get a low rating with a total of 5 types of risk.

The results of the assessment show that in 2019 there was a change with the type of operational risk which was previously low to moderate increasing to moderate which lasted until 2020. This also happened to compliance risk and the composite rating which was previously considered low in 2017-2018 increased to low to moderate in 2019 to 2020.

\section{Active Supervision of the Board of Commissioners and Board of Directors}

The supervisory function carried out by the board of commissioners is through: the audit committee, risk monitoring committee and integrated governance committee, while the 
risk policy function through the executive committee related to risk management, namely the risk management \& credit policy committee, asset and liabilities committee, capital and subsidiaries committee, and integrated risk committee is carried out by the board of directors. In the operational section, the functions of risk identification, risk measurement, risk mitigation, and risk control are the risk management work unit along with the business unit and compliance work unit.

\section{Policies, Procedures and Limit Setting}

PT Bank Mandiri has implemented a risk management policy which is the main basis for implementing risk management. In more specific business areas, companies have more specific policies and procedures. In addition, the company has also made a policy that regulates the setting of limits for each activity, both on the portfolio and transactional labels. All of these policies are evaluated and updated at least once a year.

\section{Process of Identification, Measurement, Monitoring, and Risk Management Information System}

PT Bank Mandiri has established a process for identification, measurement, monitoring, risk control, and a risk management information system through an framework enterprise risk management. The company's implementation is through a approach twoprong. This approach is taken to find out that risk can be prevented in the event of an unexpected situation by making a capital reserve.

\section{Internal Control System}

PT Bank Mandiri implements effective risk management practices in all work units by implementing a policy three line of defense models with the following provisions:

a. The work unit as risk owner is the first line of defense that has responsibility for managing the risk of the work unit.

b. The unit risk management acts as the second line of defense that carries out the function oversight.

c. The internal audit unit is the third line of defense that carries out the function independent assurance.

\section{Non-Performing Loans}

PT Bank Mandiri has a strategy in making its company grow in a healthy and manner sustainable, by always prioritizing the principle of prudence through lending to sectors with lower credit risk and strengthening the implementation of risk management. Several attempts were made by the company to resolve non-performing loans, namely:

a. Conduct account assessment a thorough of non-performing loans that are included in the category watchlist and continue with mapping to project debtors who are still performing and who have the potential to downgrade.

b. Carry out credit rescue efforts for watchlist debtors by accelerating credit restructuring for debtors who have good intentions, business prospects and financial conditions are getting better as well as collateral with security coverage ratios adequate. 
c. Carry out credit rescue efforts for debtors non-performing through rescheduling, reconditioning and restructuring, including through converting loans into temporary equity participation.

d. Conduct post-restructuring debtor reviews, including assessing the debtor's business prospects while taking into account market conditions and the economic sector that is the debtor's business that may affect the debtor's performance and repayment capacity.

e. For loans that cannot be restructured, immediately efforts to decrease the debit balance (downsizing).

f. Improve coordination and cooperation with stakeholders in handling non-performing loans, including PPATK, Private Auction Centers, prosecutors, curators, and others.

\section{Ratio Analysis of Non-Performing Loan PT Bank Mandiri's}

This study uses Non-Performing Loan (NPL) analysis, the data used in this analysis is data on non-performing loans and total loans at PT Bank Mandiri (Persero) Tbk during the period 2017 to 2020, which can be seen in the following table:

Table 2. Collectible Credit Bank from 2017 to 2020 (in billion rupiah)

\begin{tabular}{|l|l|l|l|l|}
\hline \multicolumn{1}{|c|}{ Description } & \multicolumn{1}{c|}{$\mathbf{2 0 1 7}$} & \multicolumn{1}{c|}{$\mathbf{2 0 1 8}$} & \multicolumn{1}{c|}{$\mathbf{2 0 1 9}$} & \multicolumn{1}{c|}{$\mathbf{2 0 2 0}$} \\
\hline Current & 596.828 & 669.875 & 734.848 & 701.951 \\
\hline Special Mention & 25.159 & 29.048 & 38.664 & 36.796 \\
\hline Non-Current & 6.046 & 3.717 & 3.373 & 2.066 \\
\hline Doubtful & 3.663 & 1.922 & 3.533 & 938 \\
\hline Jams & 12.525 & 14.405 & 11.933 & 21.852 \\
\hline Loans & 644.257 & 718.967 & 792.351 & 763.603 \\
\hline NPL & 22.234 & 20.044 & 18.839 & 24.856 \\
\hline NPL \% & $3,45 \%$ & $2,79 \%$ & $2,39 \%$ & $3,26 \%$ \\
\hline Deskription & Good & Good & Good & Good \\
\hline
\end{tabular}

Source: Annual Report of Bank Mandiri (processed, 2021)

Based on the Table 2 shows that the average Non-Performing Loan (NPL) of PT Bank Mandiri (Persero) Tbk is still below Bank Indonesia regulations. The provisions made by Bank Indonesia are Non-Performing Loans (NPL) below 5\% can be said to be good. When viewed from each year the non-performing loans at PT Bank Mandiri (Persero) Tbk fluctuated.

In 2017 PT Bank Mandiri (Persero) Tbk had non-performing loans of Rp. 12,525, when viewed from the previous year this non-performing loan increased, with a total loan of Rp. 644.257. Thus, obtaining a Non-Performing Loan (NPL) of 3.45\%, Non-Performing Loan PT Bank Mandiri (Persero) Tbk's (NPL) in 2017 is under Bank Indonesia regulations. Then in 2018 the non-performing loans owned by PT Bank Mandiri (Persero) Tbk were Rp. 14,405 , this year also experienced an increase in non-performing loans with a total loan of Rp. 718,967. So that the results of Non-Performing Loans (NPL) amounted to $2.79 \%$.

In 2019 this non-performing loan decreased to Rp. 11,933 with an increased total credit of Rp. 792,351. So the value of Non-Performing Loan (NPL) is 2.39\%. Nonperforming loans in 2020 increased again by Rp. 21,852. However, total credit decreased by Rp. 763,603, while the Non-Performing Loan (NPL) obtained in 2020 was 3.26\%. So that 
when viewed as a whole, an average value of $3.17 \%$ is obtained for the years 2017 to 2020 . The average results are in accordance with the criteria for assessing the level of health ratio according to Bank Indonesia, which is less than 5\%, then the average Non -Performing Loan (NPL) owned by PT Bank Mandiri (Persero) Tbk in 2017-2020 received a good predicate.

As a result of the decrease and increase in Non-Performing Loans (NPL) from 20172020 , this occurred due to funds with a rate of return that did not match the payback period caused by customers experiencing difficult conditions to pay and in 2020 Non-Performing Loans (NPLs) increased caused by the implementation of PPKM due to the Covid-19 outbreak.

\section{F. CONCLUSION}

Based on the results of the research and discussion described earlier, it shows that the management at PT Bank Mandiri (Persero) Tbk has been implemented properly. Implementation of PT Bank Mandiri (Persero) Tbk risk management in accordance with risk management policies and regulations from Bank Indonesia, such as active supervision of the board of commissioners and directors, policies, procedures and limit setting, identification, measurement, monitoring, and risk management information systems. internal control. The results of this study also show that Non-Performing Loans (NPLs) on PT Bank Mandiri (Persero) Tbk is below 5\% which can be said to be in accordance with good criteria. Thus, the Non-Performing Loan (NPL) on PT Bank Mandiri (Persero) Tbk is included in the level of good criteria.

In this study, it has limitations that only perform an analysis of non-performing loans or non-performing loans Non-Performing Loans (NPL) only in one banking company with a period of 5 years. However, for further research, it is expected to be able to conduct analysis with several banking companies as research objects with different year periods.

\section{REFERENCES}

Arifudin, O. (2020). Risk Management. Widina Bhakti Persada.

Desda, M. M., \& Yurasti. (2019). Analysis of the Application of Credit Risk Management in Minimizing Non-Performing Loans at PT. BPR Swadaya Anak Nagari Bandarejo Simpang Empat Period 2013-2018. MBIA Journal, 18(1), 94.

Fachrizah, H. (2021). How to Overcome Loan Installment Congestion Problems. Retrieved from: https://www.ukmindonesia.id/baca-article/366

Kasmir. (2016). Banking Fundamentals. Depok: RajaGrafindo Persada.

Musdahlia. (2020). Application of Risk Management on Financing at Bank Muamalat KCP Palopo. Retrieved from: http://repository.iainpalopo.ac.id/id/eprint/3170/1/SKRIPSI MUSDALIA.pdf

Financial Services Authority. (2016). Guidelines for Calculation of Risk-Weighted Assets for Credit Risk Using Standard Approach (Patent No. 42 /SEOJK.03/2016). https://www.ojk.go.id/id/regulation/Documents/Pages/POJK-about-Guidelines-

Perhitungan-Aset-Terweighted-According-Risiko-for-Risiko-Kredit-with-

Menggunakan-Percepatan-Standar/seojk 42-2016.pdf

Pratama, R., \& A. Samiun, A. (2019). Implementation of Risk Management to Minimize Bad Credit Risk at PT. BPRS Bahari Berkesan. Journal of Management Partners, 3(9), 932-945. https://doi.org/10.52160/ejmm.v3i9.283 
Putri, R. N. O. S. (2017). The Influence of Credit and Capital Adequacy Levels on Profitability Levels in Banking Companies listed on the Indonesia Stock Exchange. Journal of Management Unud, 6(10).

Sugiyono. (2018). Management Research Methods. Bandung: Alfabeta.

Supriyono, R. A. (2018). Behavioral Accounting. Gajah Mada.

Wahjusaputri, A. T. (2018). Banks and Financial Institutions. Media Discourse Partners. 